\title{
Profile and Competencies of Nurse Managers at Accredited Hospitals ${ }^{1}$
}

\author{
Patrícia de Oliveira Furukawa² \\ Isabel Cristina Kowal OIm Cunha ${ }^{3}$
}

\begin{abstract}
This descriptive study identified the profile and competencies of nurse managers of accredited hospitals from the their perspective and that of their hierarchical superiors. It was conducted in 14 hospitals certified by the National Organization of Accreditation and the Joint Commission International in São Paulo, SP, Brazil. Data were collected through two questionnaires that were applied to 24 professionals. The nurse managers' profiles showed that $69.2 \%$ came from private colleges, all with more than 10 years experience since graduation and $92.3 \%$ had attended a post-degree program in health management. The nurse managers' most frequent competencies according to their superiors were: leadership, focus on patients, and teamwork. The conclusion is that the profile and competencies of most of the nurse managers were compatible with the expectations of their superiors, who collaborate in the selection of candidates for the nurse manager position and evaluate their professional performance.
\end{abstract}

Descriptors: Nursing; Professional Competence; Management; Accreditation.

\footnotetext{
${ }^{1}$ Paper extrated from Master's Thesis "Perfil e Competências de Gerentes de Enfermagem de Hospitais de Qualidade" presented to Universidade Federal de São Paulo, SP, Brazil. Supported by CAPES.

${ }^{2}$ RN, M.Sc. in Sciences, Universidade Federal de São Paulo, SP, Brazil. E-mail: patricia.furukawa@unifesp.br.

${ }^{3}$ RN, Ph.D. in Health Sciences, Adjunct Professor, Universidade Federal de São Paulo, SP, Brazil. E-mail: isabel.cunha@unifesp.br.
}

Corresponding Author:

Isabel Cristina Kowal Olm Cunha

Universidade Federal de São Paulo. Departamento de Enfermagem.

Rua Napoleão de Barros, 754

Vila Clementino

CEP: 04024-002 São Paulo, SP, Brasil

E-mail: isabelcunha@unifesp.br 


\section{Perfil e competências de gerentes de enfermagem de hospitais acreditados}

Estudo descritivo que teve como objetivo identificar o perfil e as competências de gerentes de enfermagem de hospitais acreditados, sob a ótica desses e de seus superiores hierárquicos, desenvolvido em 14 hospitais certificados pela Organização Nacional de Acreditação e pela Joint Commission International do Município de São Paulo. Para a obtenção dos dados, foram elaborados dois questionários respondidos por 24 profissionais. O perfil dos gerentes de enfermagem revelou que 69,2\% vieram de faculdades privadas, todos com mais de 10 anos de formação e 92,3\% com pósgraduação na área de gestão em saúde. As competências que mais possuíam, na visão dos seus superiores hierárquicos, foram: liderança, foco no cliente e trabalho em equipe. Conclui-se que a maioria dos gerentes de enfermagem possuía semelhanças quanto ao perfil e competências, compatíveis com as expectativas de seus superiores hierárquicos que colaboraram na seleção para o cargo e na avaliação de seu desempenho profissional.

Descritores: Enfermagem; Competência Profissional; Gerência; Acreditação.

\section{Perfil y competencias de gerentes de enfermería de hospitales acreditados}

Estudio descriptivo que tuvo como objetivo identificar el perfil y las competencias de gerentes de enfermería de hospitales acreditados bajo la óptica de estos y de sus superiores jerárquicos, desarrollado en 14 hospitales certificados por la Organización Nacional de Acreditación y por la Joint Commision International del Municipio de Sao Paulo. Para la obtención de los datos, fueron elaborados dos cuestionarios respondidos por 24 profesionales. El perfil de los gerentes de enfermería reveló que 69,2\% eran provenientes de facultades privadas, todos con más de 10 años de formación y 92,3\% con posgraduación en el área de gestión de la salud. Las competencias que más poseían, en la visión de sus superiores jerárquicos fueron: liderazgo, enfoque en el cliente y trabajo en equipo. Se concluyó que la mayoría de los gerentes de enfermería poseían similitudes en cuanto al perfil y competencias, compatibles con las expectativas de sus superiores jerárquicos que colaboraron en la selección para el cargo y en la evaluación de su desempeño profesional.

Descriptores: Enfermería; Competencia Profesional; Gerencia; Acreditación.

\section{Introduction}

Transformations that arise from globalization and consequent increased competitiveness have required organizations to change, even health facilities, which have begun to review their management models to improve the quality of their services through accreditation programs. Criteria used by these programs concerning the evaluation of nursing services include primarily administrative and organizational areas followed by care and teaching-research fields ${ }^{(1)}$.

From this perspective, the nurse manager has played an important role in health services, especially in the hospital sphere, since this professional is responsible for the management of nursing services and for taking measures that include the administrative, care and teaching-research areas with a view to deliver quality care. The requirements concerning the work of nurse managers include, in addition to the management of nursing, knowledge and interaction with the entire organizational environment in order to contribute to the success of the institution. 
For that, organizations have demanded professionals with profiles and competencies that enable high performance and collaboration in working toward organizational goals. The idea that individual competencies have a close relation with organizational strategies and competencies has gained the spotlight in professional and academic spheres. The relationship established through mutual development in which individuals are valued by the organization as they effectively contribute to its development and the organization is valued by individuals as it offers concrete conditions for their development, meets the expectation of people increasingly concerned with obtaining more satisfaction and personal realization and also securing their inclusion in the job market ${ }^{(2)}$.

But what is the profile and competence necessary for a nurse manager? There are few studies addressing this function and answering such a question. Six categories of competency emerged in a study conducted by the Nursing Leadership Institute(3) addressing nurse managers of hospitals and public health agencies in the USA. These categories were based on the study's results that included: personal domain, interpersonal efficacy, financial management, human resources management, care (of the personnel, patients and themselves) and systematized thinking.

A study carried out in Brazil by the Regional Council of Nursing in the state of São Paulo (CORENSP) with technical nurses responsible for health services established the need for the following competencies: leadership, communication, decision-making, negotiation, teamwork, interpersonal relationships, flexibility, entrepreneurship, creativity, systemic view, planning and organization(4).

To identify the profile and competencies necessary in nurse managers, not only in the opinion of nurses, but also from the organization's viewpoint. Since such competencies reflect the needs manifested by the job market and the population, which demand competent professionals aware of their roles, this study's objectives are the following: to characterize the profile of nurse managers of accredited hospitals, identify strategies used to select these professionals; compare the opinions of nurse managers and those hierarchically above them in relation to the competencies necessary for the job; and identify the competencies of these nurse managers from the perspective of their superiors.

\section{Methods}

This descriptive study with a quantitative approach was conducted in hospitals of the city of São Paulo, SP,
Brazil accredited by the Joint Commission International (JCI) and by the National Accreditation Organization (ONA). Of the 20 contacted institutions, 14 (70\%) consented to participate in the study.

The sample was composed of nurse managers and their superiors, called in this study of directors, who agreed to participate in the study through free and informed consent forms. The inclusion criteria for nurse managers were: being a nurse and having a managing function in the hospital nursing service. And the inclusion criteria for the directors were: being the professionals to whom nurse managers reported within the hierarchy. The exclusion criterion, both for nurse managers and directors, included: being professionals recently designated to such functions (less than six months), a time we deemed insufficient to evaluate the profile and competence of nurse managers.

Two of the 14 studied hospitals were managed by the same professionals, totaling 26 professionals (13 nurse managers and 13 directors). The sample was composed of $13(72.2 \%)$ nurse managers and 11 $(61.1 \%)$ directors; one of the directors was excluded and another did not answer the questionnaire.

To comply with the requirements of the Ethics Research Committee at the Federal University of São Paulo (UNIFESP), authorization was asked of all the institutions, while five hospitals demanded that the project be submitted to their respective ethics committees. After the project was authorized by all the institutions, it was approved through protocol 1122/08 on August $1^{\text {st }} 2008$.

Two questionnaires were developed to collect data: one designed for the nurse managers and the other for the directors. The data collection instruments were developed and pre-tested considering the proposed objectives and the literature. The theoretical framework used to define the competencies contained in the instruments was based on the concept proposed by Dutra $^{(5)}$, that is, one's ability to surrender oneself and add value to the organization's set of knowledge. Evaluating people by their ability to surrender enable us to more properly evaluate them and guide their development, establishing rewards tied to the organization's strategies. Data collection was carried out between September $8^{\text {th }}$ and November $19^{\text {th }}, 2008$.

The categorical variables (demographic data, education, professional experience, selection of nurse managers, directors' characteristics, view of directors versus the profiles and competencies nurse managers possess in the view of directors) were descriptively 
analyzed through absolute and relative frequencies. The numeral variables (classification of competencies attributed by directors and nurse managers) were statistically summarized: average, standard deviation, minimum, median and maximum. The comparison of the classification of competencies between directors and nurse managers was performed using Wilcoxon's test. The analyses were obtained by the use of the statistical software Minitab version 15.1; statistical significance was established for values at $p<0.05$.

\section{Results}

The thematic categories that resulted from the analysis of results and that allowed the study to achieve the proposed objectives were: profile of nurse managers, selection of nurse managers, characteristics of directors, view of directors versus the nurse managers' profiles, and evaluation of competencies.

\section{Nurse managers' Profile}

The profiles described in Table 1 show that the nurse managers were 44 years old on average, with a range from 38 to 49 years old. The sample was predominantly female and married, with one to two children. In relation to education, most graduated from private colleges more than 10 years ago and had a specialization; a minority had an MBA. In Brazil, individuals who attend these two post-degree programs are not entitled to a degree, however while a specialization program allows the individual to specialize in his/her field, the latter is designed to educate executives in the management field.

Almost all the individuals attended some management program in the health field. About half of the individuals attended a master's or doctoral program. Most of the nurse managers had worked for more than 10 years in the institution and worked in other care and administrative functions before becoming nurse managers. Of these, few had any experience in management before assuming the job.

Table 1 - Profile of Nurse managers, São Paulo, SP, Brazil - 2008

\begin{tabular}{lcc}
\hline \multicolumn{1}{c}{ Characteristics } & N & $\%$ \\
\hline Age & & \\
31 to 40 years old & 01 & 7.7 \\
41 to 50 years old & 12 & 92.3 \\
& & (continue...)
\end{tabular}

Table 1 - (continuation)

\begin{tabular}{|c|c|c|}
\hline Characteristics & $\mathbf{N}$ & $\%$ \\
\hline \multicolumn{3}{|l|}{ Gender } \\
\hline Male & 01 & 7.7 \\
\hline Female & 12 & 92.3 \\
\hline \multicolumn{3}{|l|}{ Marital Status } \\
\hline Single & 03 & 23.1 \\
\hline Married & 10 & 76.9 \\
\hline \multicolumn{3}{|l|}{ Children } \\
\hline Yes & 07 & 53.9 \\
\hline No & 06 & 46.1 \\
\hline \multicolumn{3}{|l|}{ College } \\
\hline Public & 04 & 30.8 \\
\hline Private & 09 & 69.2 \\
\hline \multicolumn{3}{|l|}{ Graduate Programs } \\
\hline Specialization & 13 & 100 \\
\hline MBA & 05 & 38.5 \\
\hline Master's Degree & 06 & 46.2 \\
\hline Doctoral Program & 01 & 7.7 \\
\hline \multicolumn{3}{|l|}{ Time in the institution } \\
\hline From 6 months to 5 years & 01 & 7.7 \\
\hline 05 to 10 years & 03 & 23.1 \\
\hline 10 to 15 years & 04 & 30.8 \\
\hline$>15$ years & 05 & 38.4 \\
\hline \multicolumn{3}{|l|}{ Time in the function } \\
\hline$<5$ years & 06 & 46.2 \\
\hline 05 to 10 years & 06 & 46.2 \\
\hline 10 to 15 years & 01 & 7.7 \\
\hline \multicolumn{3}{|l|}{ Previous Experience } \\
\hline Care nurse & 13 & 100 \\
\hline Nursing Supervision & 10 & 76.9 \\
\hline Nursing management & 04 & 30.8 \\
\hline Other fields within nursing & 04 & 30.8 \\
\hline
\end{tabular}

\section{Selection of Nurse managers}

Of the 13 nurse managers, 10 (76.9\%) had worked in other roles in the hospital before assuming this position. Of these, seven $(53.8 \%)$ were selected for the job, two (15.4\%) were submitted to a selective process and one $(7.7 \%)$ reported she followed the hospital plan of career though she did not specify what this plan involved.

Of the three $(23.1 \%)$ individuals who were not previously working in the hospital, the name of one candidate $(7.7 \%)$ was suggested by someone in the institution and two (15.4\%) participated in a selective 
process. Four nurses in total were hired through selective processes. All these reported that psychological evaluation and interviews were used as instruments of selection, while three also reported their resumes were evaluated, two underwent technical testing, one to a redaction test and the references of another candidate from other institutions were considered.

\section{Directors' characteristics}

The directors' characteristics show that most, $(8 / 72.75 \%)$, were male; six were physicians $(54.6 \%)$, three $(27.3 \%)$ were hospital administrators and two $(18.2 \%)$ were nurses, all with post-degree programs. Only five (45.5\%) reported post-degree programs in health management: two nurses and three physicians.

\section{View of Directors versus Nurse managers' Profile}

Considering that only 11 directors and 13 nurse managers participated in the study, the opinions of directors or the profile and competencies of the nurse managers of two institutions were not compared.

In relation to the profile necessary for individuals to occupy the head nurse position: eight (72.7\%) directors reported that 5 to 10 years of schooling were the minimum required and three $(27.3 \%)$ reported that more than 10 years were required. Since all the nurse managers had more than 10 years of education, all presented the minimum required by the directors, while eight $(72.7 \%)$ individuals had more than the minimum required.

In relation to the requirement that nurse managers have attended a post-degree program, only one $(9.1 \%)$ manager reported that no post-degree program was necessary and another $(9.1 \%)$ reported that only an MBA was required. The other nine $(81.8 \%)$ directors reported the need of a specialization; of these, three mentioned the need to have an MBA in addition to a specialization. None of the directors reported the need of a master's or doctoral degree. In most of the cases, in six $(54.5 \%)$ institutions, the nurse managers had attended other post-degree programs in addition to that required by the directors. Four (36.4\%) nurse managers met the directors' post-degree requirements, while one $(9.1 \%)$ of them had not attended an MBA.

In relation to minimum professional experience, only two (18.2\%) directors reported the need for nurse managers to have previous experience as care nurses, five $(45.5 \%)$ reported the need to have experience in nursing supervision with an intermediate level in the hierarchy and seven $(63.6 \%)$ in nursing management. Data from each institution showed that three (27.3\%) did not have previous experience in nursing management. Another two $(18.2 \%)$ had minimum experience and the previous professional experience of six (54.5\%) was superior to what was considered necessary by directors.

\section{Evaluation of Competencies}

Directors and nurse managers classified by order of importance the competencies that the latter should have to develop their activities. Eleven competencies were evaluated: management of resources, communication, teamwork, process management, decision-making, focus on patients, acquisition of knowledge, entrepreneurship, leadership, negotiation, and strategic view (Table 2).

Table 2 - Classification attributed to competencies by directors and nurse managers, São Paulo, SP, Brazil - 2008

\begin{tabular}{|c|c|c|c|c|c|c|c|c|}
\hline Competence & View & $\mathbf{N}$ & average & S.D. & $\min$. & median. & $\max$. & $\mathbf{p}$ \\
\hline \multirow[t]{2}{*}{ Resource management } & Director & 11 & 5.9 & 2.0 & 4 & 6 & 11 & 0.059 \\
\hline & Nurse manager & 11 & 7.7 & 2.7 & 3 & 9 & 11 & \\
\hline \multirow[t]{2}{*}{ Communication } & Director & 11 & 6.7 & 2.8 & 2 & 7 & 11 & 0.351 \\
\hline & Nurse manager & 11 & 5.6 & 2.6 & 2 & 6 & 10 & \\
\hline \multirow[t]{2}{*}{ Teamwork } & Director & 11 & 4.5 & 3.3 & 1 & 3 & 9 & 0.477 \\
\hline & Nurse manager & 11 & 5.2 & 1.8 & 2 & 5 & 9 & \\
\hline \multirow[t]{2}{*}{ Process management } & Director & 11 & 5.5 & 3.1 & 1 & 4 & 10 & 0.721 \\
\hline & Nurse manager & 11 & 6.0 & 2.0 & 3 & 5 & 10 & \\
\hline \multirow[t]{2}{*}{ Decision-making } & Director & 11 & 4.9 & 2.5 & 2 & 5 & 11 & 0.221 \\
\hline & Nurse manager & 11 & 6.3 & 2.8 & 3 & 7 & 10 & \\
\hline \multirow[t]{2}{*}{ Focus on patients } & Director & 11 & 5.3 & 2.7 & 1 & 5 & 10 & 0.722 \\
\hline & Nurse manager & 11 & 5.8 & 3.2 & 2 & 6 & 11 & \\
\hline \multirow[t]{2}{*}{ Acquisition of knowledge } & Director & 11 & 8.3 & 3.0 & 1 & 9 & 11 & 0.919 \\
\hline & Nurse manager & 11 & 8.8 & 2.9 & 2 & 10 & 12 & \\
\hline
\end{tabular}


Table 2 - (continuation)

\begin{tabular}{|c|c|c|c|c|c|c|c|c|}
\hline Competence & View & $\mathbf{N}$ & average & S.D. & $\min$. & median. & $\max$. & $\mathbf{p}$ \\
\hline \multirow[t]{2}{*}{ Entrepreneurship } & Director & 11 & 8.7 & 3.0 & 3 & 10 & 11 & 0.678 \\
\hline & Nurse manager & 11 & 8.4 & 2.5 & 4 & 10 & 11 & \\
\hline \multirow[t]{2}{*}{ Leadership } & Director & 11 & 3.0 & 2.5 & 1 & 2 & 8 & 0.722 \\
\hline & Nurse manager & 11 & 2.6 & 2.3 & 1 & 2 & 8 & \\
\hline \multirow[t]{2}{*}{ Negotiation } & Director & 11 & 8.1 & 1.8 & 5 & 8 & 11 & 0.541 \\
\hline & Nurse manager & 11 & 6.7 & 3.9 & 1 & 8 & 11 & \\
\hline \multirow[t]{2}{*}{ Strategic view } & Director & 11 & 5.1 & 3.6 & 1 & 5 & 11 & 0.445 \\
\hline & Nurse manager & 11 & 3.6 & 3.2 & 1 & 2 & 9 & \\
\hline
\end{tabular}

There was no statistically significant difference between the classification attributed by directors and nurse managers, indicating that these professionals had similar opinions concerning the order of importance of the competencies necessary for nurse managers. However, the statistical difference in the case of the competence resources management was too close to the significance $(p=0.059)$ indicating that directors value this competence more than nurse managers.

The most important competencies in the opinion of both professionals were: leadership, strategic view, teamwork, focus on patients, and management of processes. In the evaluation performed by the nurse managers' superiors concerning their competencies, the following were identified: leadership, focus on patients, decision-making, teamwork (Table 3).

Table 3 - Classification of importance of competencies and number of nurse managers who possess such competencies in the view of directors, São Paulo, SP, Brazil - 2008

\begin{tabular}{clcll}
\hline Classification of Directors & $\begin{array}{c}\text { Nurse managers who possess } \\
\text { the competence according to the } \\
\text { directors' evaluation }\end{array}$ & $\begin{array}{c}\text { Classification of Nurse } \\
\text { managers }\end{array}$ & $\begin{array}{c}\text { Nurse managers who possess } \\
\text { the competence according to the } \\
\text { directors' evaluation }\end{array}$ \\
\hline $1^{\circ}$ & Leadership & $10(90.9 \%)$ & $1^{\circ}$ & Leadership \\
$2^{\circ}$ & Teamwork & $8(72.7 \%)$ & $2^{\circ}$ & Strategic view \\
$3^{\circ}$ & Decision-making & $9(81.9 \%)$ & $3^{\circ}$ & Teamwork \\
$4^{\circ}$ & Strategic view & $7(63.6 \%)$ & $4^{\circ}$ & Communication \\
$5^{\circ}$ & Focus on patients & $10(90.9 \%)$ & $5^{\circ}$ & Focus on patients \\
$6^{\circ}$ & Process management & $7(63.6 \%)$ & $6^{\circ}$ & Process management \\
$7^{\circ}$ & Resource management & $9(81.8 \%)$ & $7^{\circ}$ & Decision-making \\
$8^{\circ}$ & Communication & $9(81.8 \%)$ & $8^{\circ}$ & Negotiation \\
$9^{\circ}$ & Negotiation & $8(72.7 \%)$ & $9^{\circ}$ & Resource management \\
$10^{\circ}$ & Acquisition of knowledge & $8(72.7 \%)$ & $10.7 \%)$ \\
$11^{\circ}$ & Entrepreneurship & $5(45.5 \%)$ & $10^{\circ}$ & Entrepreneurship \\
\hline
\end{tabular}

\section{Discussion}

The predominance of women in this role refers to the profession socio-historical aspects. Even though the number of male nurses has increased in recent years, the attractiveness of college education has not been sufficient for men to view nursing as a professional option(6). It explains, in part, the difference of this profession in relation to other professions included in the Brazilian largest organizations', in which women occupy in average $24.6 \%$ of the management positions ${ }^{(7)}$.

Because it is a predominantly female profession, nursing professionals deal with the dynamics of the organizations in the performance of their activities at the same time they manage their lives as people, wives and mothers ${ }^{(8)}$. A study addressing the stress of nurses indicated that the activities related to the personal life such as: responsibilities with the house, with children, and other activities at home, can function as a support instead of being stressors ${ }^{(9)}$.

The education of these nurses who, in the main, originate from private colleges reflects the expansion of higher education programs in Brazil. According to data from the National Institution of Studies and Educational Research (INEP) there are 779 nursing programs authorized in the country. Of these, 627 (80.5\%) are 
from private schools and only 152 (19.5\%) from public schools. In the state of São Paulo, this figure increases to $91.1 \%$ are private nursing programs and $8.9 \%$ public schools $^{(10)}$.

To complement and qualify this education in specific fields, nurses seek post-degree programs. All the nurse managers in the studied group had attended specialization programs and few of these also pursued an MBA. However, almost all nurse managers attended some post-degree program in health management.

Therefore, after attending a specialization program, a large number of these professionals opted to attend master's and doctoral programs, which are academic and research-oriented, with an essentially scientific goal, while specialization has a practical professional nature. Master's and doctoral programs are a system that educates an essential stratum higher in the hierarchy of educational programs that composes higher education. Hence, the nature of these programs implies a high intellectual selectiveness, which attributes a special status to them ${ }^{(11)}$.

In relation to professional experience, most of the studied nurse managers had worked for many years in the institution, working in other functions before ascending to the position of nurse manager. If, on the one hand, experience in care delivery enables nurses to manage others according to the needs presented by practice, on the other hand, it indicates that one of the few ways nurses ascend in health organizations has been a change to a managerial career trajectory.

Despite the fact that the education of nurses generally includes aspects of management in a very significant way, this mobility may not be positive for the institution and professionals. Hence, it is important to precisely establish the criteria of mobility among careers of different natures since a classical example in organizations is the migration of the best technical professionals to a managerial career and not the person with that vocation. That is why the managerial career is frequently seen as an award, an acknowledgement of the individual's contribution to the organization and not as a new career(5).

The fact that the names of most of the nurse managers were suggested by someone in the institution shows that the criteria used by these hospitals in the selection of nurse managers have involved the professional's history and performance in the organization instead of instruments of analysis aiming to identify which candidate best fits the profile. It is important to consider that the competencies required of individuals in a professional path are different from those required in a managerial role. Hence, not only the individual's previous performance but also the individual's ability to deal with the responsibility of the new role needs to be evaluated. For that, before this migration, professionals with the potential to work in the managerial field need to be gradually developed and challenged to apply newly acquired competencies ${ }^{(5)}$.

The analysis of the opinions of the directors concerning the ideal profile of a nurse manager revealed that these, given the different organizational structures, occupy varied functions. A tendency observed in some hospitals is the integration of the various multiprofessional areas linked to care delivery under a single supervision. Even though nurses, while in these functions, assume the direction of strategic levels of organizations, these functions are usually occupied by physicians. However, nurses are a minority among those who report a post-degree degree in health management, which reinforces the view that nurses are acknowledged in daily practice as professionals with the competence to administrate but historical circumstances and gender relations do not nurses to fill this role and few health facilities are managed by a nurse ${ }^{(12)}$.

The ideal profile for nurse managers, according to directors, concerning professional experience shows that there is a preference among these institutions for nurses with greater professional experience to occupy this position instead of newly graduated nurses, which is compatible with the profile presented by the nurse managers. This fact also aligns with another study addressing nurse managers who had in general more than 10 years experience since graduation, as well as having professional experience. This position was considered by these professionals as part of a strategy of nurses based on previous education and experiences ${ }^{(13)}$.

In relation to a post-degree degree, specialization programs and MBAs are among the requirements; a master's or a doctoral degree is not valued by directors, which is contrary to the tendency of nurse managers working in the care field and who seek such degrees. From this perspective, the MBA, which is a recently developed program, especially in the health field, should be better explored by nurses working or who desire to work in management or direction functions, since according to this study's results, few nurse managers attended such programs, though this was one of the main requirements in the opinion of directors.

In relation to professional experience, a large number of directors reported the need for greater experience in nursing supervision and management. However, when professionals are internally selected for 
this function, experience ends up not being essential in these cases, as is observed when the profiles of these professionals are compared.

The similar opinions among nurse managers and directors regarding the classification of competencies show these professionals are attuned to the importance of each competence in the performance of nurse managers. The issue concerning the origin of individual competencies is essential to characterizing the expectations of the organization in relation to individuals, who will be better oriented in their activities, in their development and career opportunities ${ }^{(5)}$.

Leadership is considered the most important competence by both professionals and the effort of nurse managers to develop such competence reinforces the view that the job market is actually demanding nurses have knowledge of leadership and apply such knowledge and professionals are aware of the demand(14).

Teamwork is among the three most important competencies, developed by most of the nurses $(72.7 \%$ of the studied nurse managers), developed by nurses to promote the integration of the team's members to improve results. However, not all nurses possess this competency, which demands attention given the level of importance of this competence in achieving organizational objectives.

In nursing, the proposal of teamwork emerged in the 1950s in the USA through experiences orchestrated by the Teacher's College Columbia University, under the supervision of Eleonor Lambertsen who defended the organization of nursing services based on teamwork as a solution to the issue of better use of personnel. Even though the concept of teamwork was first introduced in the nursing field, it was consolidated only in discourse, not as a predominant practice ${ }^{(15)}$, while the work is oftentimes performed in a fragmented way.

Florence Nightingale showed the importance of applying science in the administration of hospitals and aiming to improve care delivered to patients, nurses assumed administrative function in health institutions ${ }^{(16)}$. However, these professionals ended up become detached from their object of work - care delivery. In this context, nurses developed a management style mainly focused on the needs of the service, compliance with regulations, standards and tasks, reproducing what is recommended by the organization and other professionals, which have often led them to not meet the needs of patients, causing dissatisfaction within the nursing team ${ }^{(17)}$.

Given the movement of nurses to recover what should be their main object of work and the concern of institutions to meet the needs of patients, whether this concern is motivated by quality programs or by the need to survive in the market, focusing on patients and allying the organizational objectives to the patients needs, has been crucial in the performance of nurse managers. Because this is one of the competencies that the nurse managers have the most, it shows that these nurses have the understanding that even though their work process is predominantly managerial, their actions should be directed toward improved care delivery, which cannot be lost sight of.

Strategic view, despite the fact it has been recently applied in nursing, was considered second in importance by nurse managers and it is the fourth most important according to directors. Its development was previously related to the high level administration responsible for defining the guidelines of the organization. However, at the tactical level, related to managerial and coordination levels, professionals need to know what is happening in the external environment to enable internal strategies ${ }^{(18)}$. A little more than half of nurse managers had this competence according to their superiors. Hence, these professionals need to be able to develop a strategic view.

Process management has also been valued in hospitals, especially through the search for quality through accreditation that evaluates the organization in a systemic way where structures and processes are related and interfere in the entire organization(19). Therefore, the management of processes is another competence that needs to be developed by nurse managers.

Resource management is the only competency that presented, on average, a disagreement between the two professionals; the nurse managers classified it as one of the least important. The management of resources in the hospital field is related to costs in addition to the need to ensure appropriate working conditions for professionals to deliver care to patients. Nurses have been responsible for managing material and physical resources that demand a large volume of financial resources. Depending on the facility, human resources in nursing represent $30 \%$ to $60 \%$ of the total of the personnel(20). Hence, nursing has an important impact on hospital costs and the rational use of resources and reduced waste. Nursing also favors not only the survival of organizations but also the delivery of care at lower costs, enabling larger investments in quality. This competency was more valued by directors than by nurse managers as shown in the study's results.

\section{Final considerations}

This study revealed similarities in the profile and competencies of nurse managers in accredited hospitals 
compatible with the expectations of their superiors, who help to select individuals for the job and evaluate their professional performance, indicating a direction for nurses who desire to develop a managerial career or desire to change the context presented here.

We also believe that teaching institutions can use this study to develop nurses' managerial competencies compatible with the demands of the job market and also contribute to hospital facilities in the search to develop nurse managers who contribute to the improvement of service quality.

It is important to keep in mind that even if health organizations can serve as a benchmark, each organization should map what individual competencies are necessary according to organizational competencies and strategies, seeking to integrate with the other process management: development, movement, and valorization of personnel, aiming for the development of both organization and professionals.

\section{References}

1. Feldman LB, Cunha ICKO. Identification of result evaluation criteria for nursing service in hospital accreditation programs. Rev. Latino-Am. Enfermagem. 2006;14(4):540-5.

2. Dutra JS. Prefácio. In: Balsanelli AP, Cunha ICKO, Feldman LB, Ruthes RM (Org. ). Competências Gerenciais: desafio para o enfermeiro. São Paulo: Martinari; 2008. $208 \mathrm{p}$.

3. Sherman RO, Bishop M, Eggenberger T, Karden R. Development of a leadership competency model. JONA. 2007;37(2):85-94.

4. Conselho Regional de Enfermagem de São Paulo. Projeto Competências. São Paulo; 2009 [acesso em: 06 julho 2009]. Disponível em: http://www.coren-sp.gov. br/drupal6/sites/default/files/Projeto_Competencias.pdf 5. Dutra JS. Competências: conceitos e instrumentos para a gestão de pessoas na empresa moderna. São Paulo: Atlas; 2004. 206 p.

6. Lopes MJM, Leal SMC. A feminização persistente na qualificação profissional da Enfermagem brasileira. Cad Pagu. 2005;(24):105-25.

7. Instituto Ethos de Empresas e Responsabilidade Social e Ibope Inteligência. Perfil social, racial e de gênero das 500 maiores empresas do Brasil e suas ações afirmativas - Pesquisa 2007. São Paulo: Instituto Ethos; 2007.

8. Spindola T, Santos RS. Woman and work: the history of life of nursing professionals who are also mothers. Rev. Latino-Am. Enfermagem. 2003;11(5):593-600.
9. Stacciarini JMR, Tróccoli BT. The stress in nursing professionel. Rev. Latino-Am. Enfermagem. 2001;9(2):17-25.

10. Ministério da Educação (BR). Instituto Nacional de Estudos e Pesquisas Educacionais (INEP). Educação Superior: cursos e instituições. [acesso em: 20 junho 2009]. Disponível em: http://www.inep.gov.br

11. Parecer n. 977, de 3 de dezembro de 1965 (BR). Definição dos cursos de pós-graduação. Documenta n. 44 do Conselho Federal de Educação, Brasília, 3 dezembro 1965.

12. Torres DG. Paradigma da gerência que exercem as enfermeiras na direção geral da instituição hospitalar: um estudo na perspectiva latino-americana [Tese]. Rio de Janeiro (RJ): Universidade Federal do Rio de Janeiro; 2007.

13. Brito MJM, Lara MO, Soares EG, Alves M, Melo MCOL. Traços identitários da enfermeira-gerente em hospitais privados de Belo Horizonte, Brasil. Saúde Soc. 2008; 17(2):45-57.

14. Higa EFR, Trevizan MA. The style of leadership idealized by nurses. Rev. Latino-Am. Enfermagem. 2005;13(1):59-64.

15. Peduzzi M, Ciampone MHT. Trabalho em equipe e processo grupal. In: Kurcgant P. (Coord.) Gerenciamento em Enfermagem. Rio de Janeiro: Guanabara Koogan, 2005. p. 108.

16. Santos I, Oliveira SEM, Castro CB. Gerência do processo de trabalho em Enfermagem: liderança da enfermeira em unidades hospitalares. Texto Contexto Enferm. 2006;15(3):393-400.

17. Galvão CM, Trevizan MA, Sawada NO. A liderança do enfermeiro no século XXI: algumas considerações. Rev Esc Enf USP. 1998;32(4):302-6.

18. Tajra SF. Gestão estratégica na saúde: reflexões e práticas para uma administração voltada para excelência. São Paulo: Iátria; 2006. 536 p.

19. Rodrigues EAA. Uma revisão da acreditação hospitalar como método de avaliação de qualidade e da experiência brasileira [Dissertação de mestrado] Rio de Janeiro (RJ): Escola Nacional de Saúde Pública/ FIOCRUZ; 2004. 75 p.

20. Castilho V, Fugulin FMT, Gaidzinski RR. Gerenciamento de custos nos serviços de saúde. In: Kurcgant P (Coord.) Gerenciamento em Enfermagem. Rio de Janeiro: Guanabara Koogan; 2005. p. 171-83.

Received: Jan. $13^{\text {th }} 2010$ Accepted: Dec. $10^{\text {th }} 2010$ 